\title{
Quebec considers extra billing
}

$\mathrm{Q}$ uébec Health Minister Dr. Gaétan Barrette appears to like an uphill battle. His decision to amend Bill 20 and regulate extra billing for certain procedures in publicly funded clinics has triggered outrage in the province. Doctors, patient groups and medical associations fear the measure will lead to a two-tier system that will penalize seniors and the poor. "There will be rapid access to clinics for those who can pay," Québec Ombudsperson Raymonde SaintGermain said in a release, "and slower access to hospitals for those who can't."

But Barrette makes no apol-

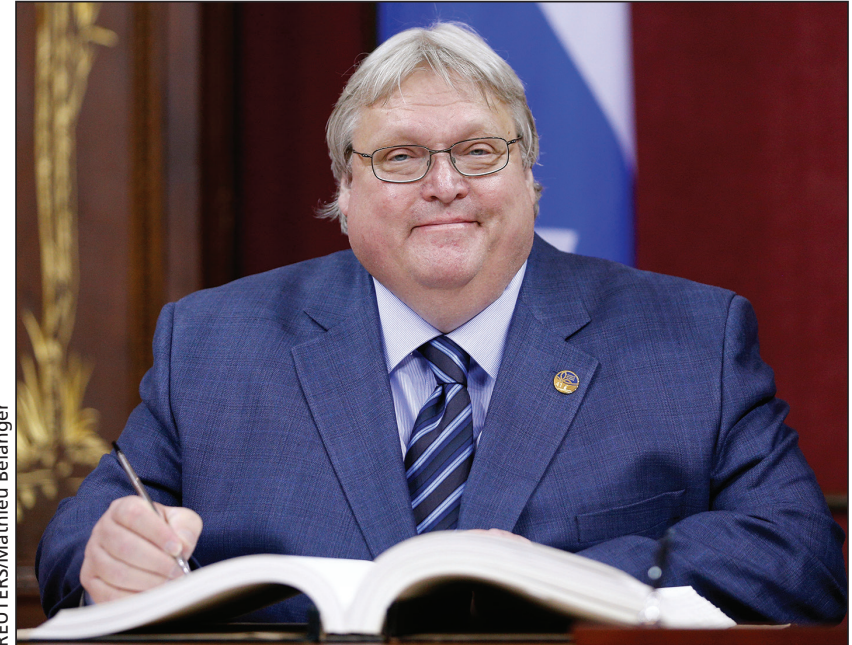

Quebec's Health Minister Gaétan Barrette introduced an amendment to Bill 20 that identifies which medical procedures and medications doctors can charge to their patients. ogies for these extra fees. Doctors in clinics have been charging their patients for 36 years and the practice is here to stay, he said. What will change, he said in an interview with $C M A J$, is that the practice will be more tightly controlled. Doctors will not be allowed to set fees as they see fit. They will have to abide by government-set prices for procedures and medications not covered by medicare or face fines and possible disciplinary measures by the Collège des médecins du Québec.

On Oct. 7, Barrette introduced an amendment to Bill 20 that will identify which medical procedures and medications doctors can bill patients for and how much they can charge. The amendment was adopted in a Parliamentary committee on Oct. 7 with no public debate and is currently before Québec's National Assembly. It is expected to become law this fall.

The move was necessary, the minister said, because rules were too vague and left too much to the imagination. "There are abuses and illegal things. We will act on this," said Barrette, who is also a radiologist.

Provinces have always had the option to determine which procedures were covered by medicare, Barrette said. For example, doctors in Quebec clinics have been billing for colonoscopies, vasectomies and X-rays for years, he said, but it was done with no controls and no guidelines. Some doctors have charged $\$ 200, \$ 300$ or $\$ 400$ for the same procedure; others charged $\$ 150$ to open a patient file, a move that is clearly illegal, said the minister.

"Fees to open a patient file, that's over," Barrette said.

But critics insist the minister is using Bill 20 as an excuse to legalize user fees through the back door. The Canadian Medical Association, the Québec Medical Association and Canadian Doctors for Medicare, among others, have come out against extra billing, a practice they feel could undermine the Canada Health Act.

Barrette rejects this notion. "There's nothing new, and over the last 36 years the federal government has not intervened. So we believe that we are not in contravention of the Canada Health Act."

Patients who use clinics expect to pay extra fees, Barrette said. The practice has become socially acceptable, he said, because people understand the health care system can only handle so much.

Not so, said Dr. Isabelle LeBlanc, head of the Médecins québécois pour le régime public, a group promoting the public health care system. She said extra billing is slowly eroding two of the guiding principles of the Canada Health Act: accessibility and universality. Extra fees are supposed to be limited to health care needs that are not covered by medicare, she said, but patients are now required to pay for procedures that are medically necessary.

"More and more, when we go to the doctor, we have to take out our credit card," she said.

The Collège des médecins du Québec asked the minister to intervene after patients complained about outrageous fees for procedures in clinics. Faced with rising costs of new technology, doctors felt they had no choice, in some cases, but to pass these expenses to patients, said Leslie Labranche, head of media relations with the college. In response, the college tightened its code of professional conduct for doctors in January of this year. It forbids doctors to charge "disproportionately" high fees to patients. When confronted, some doctors said they preferred not to offer the expensive services at all, which meant that a solution had to be found, said Labranche.

Why not ban the practice of extra billing altogether?

Simply put, the province cannot afford it, said Barrette. Québec is facing the same budgetary constraints as other provinces, only it's worse because the province has a larger aging population, and therefore faster rising health costs. Moreover, federal transfers to provinces have not kept pace with the cost of health care, added Barrette. He insists the amendment to Bill 20 is not an attempt to privatize medical care, nor is it a way to help doctors finance expensive equipment in clinics. - Huguette Young, Montréal, Que.

CMAJ 2015. DOI:10.1503/cmaj.109-5192 